vol. 25, $n^{\circ} 1 \mid 2021$

Varia

\title{
Tribute to Professor Clive Emsley
}

\section{Paul Lawrence}

\section{(2) OpenEdition}

\section{Journals}

Electronic version

URL: https://journals.openedition.org/chs/2924

DOI: $10.4000 /$ chs. 2924

ISSN: 1663-4837

\section{Publisher}

Librairie Droz

\section{Printed version}

Date of publication: 5 August 2021

Number of pages: 137-138

ISSN: 1422-0857

\section{Electronic reference}

Paul Lawrence, "Tribute to Professor Clive Emsley", Crime, Histoire \& Sociétés / Crime, History \& Societies [Online], vol. 25, $n^{\circ} 1 \mid$ 2021, Online since 05 August 2021, connection on 08 November 2022. URL: http://journals.openedition.org/chs/2924 ; DOI: https://doi.org/10.4000/chs.2924

This text was automatically generated on 8 November 2022.

All rights reserved 


\title{
Tribute to Professor Clive Emsley
}

\author{
Paul Lawrence
}

1 Clive Emsley was one of the foremost exponents of criminal justice history, a longstanding contributor to this journal and a constant friend to many members of its Editorial Board. A generous and inclusive scholar, with a vast store of knowledge and a prodigious tally of influential publications, he helped to define and develop criminal justice history from the 1970s onwards, encouraging and nurturing a new generation of researchers along the way. Publishing at least one book, article, or chapter every year in a forty-year period between 1978-2018 (and often many more), his combined bibliography includes 16 sole authored books, 17 edited books, 42 journal articles, and 46 chapters in edited collections. But it was the quality and range of these publications, rather than the quantity, which made Clive such an influential scholar.

2 Following initial research into Napoleonic France (British Society and the French Wars, 1793-1815, 1979) he soon, perhaps understandably for the son of a policeman, turned his forensic gaze on the study of the police, then in its infancy. As well as writing standard works on British policing, including Policing and its Context (1983), Crime and Society (1987), and The English Police (1991), Clive undertook arduous cross-national comparative research. Policing and its Context (1983) opened up the comparative study of modern police reform. His Gendarmes and the State in Nineteenth-Century Europe (1999) was the product of extensive archival research in France, Germany, Austria and Italy, and Crime, Police and Penal Policy (2007) provided an impressive consideration of the development of criminal justice mechanisms across Europe.

Later in his career, following his 2009 retirement from the Open University (where he had an influential and highly successful career as a teacher and academic leader), Clive turned to investigate crime and policing in military contexts. His Soldier, Sailor, Beggarman, Thief (2013) was the first serious history of criminal offending by members of the British armed forces in the twentieth century. His Exporting British Policing During the Second World War (2017) provided a comprehensive study of military policing in liberated Europe, highlighting the importance of historical precedent, given current difficulties faced by international policing organizations in enforcing democratic police reform in post-conflict societies. His penultimate book, A Police Officer and a Gentleman 
(2018), used the then little-known career of Chief Constable Michael Wilcox to demonstrate the important role British police officers played in the reconstruction of Europe after the Second World War.

4 Alongside academic publications Clive also wrote for a public audience, with popular works such as Hard Men. Violence in England since 1750 (2005) and The Great British Bobby (2009). He appeared frequently on radio and television, worked with the Police History Society and police museums, and delivered many public lectures and engaged with practitioners as well as academics and students. His work underpinned the historical outlook of a generation of criminologists, and at the Open University he helped integrate the work of historians and social scientists. Through his innovative teaching at The Open University, his scholarship reached tens of thousands of undergraduate students and he successfully supervised over twenty doctoral students, and mentored postdoctoral researchers. A truly international scholar, he held many visiting research fellowships around the world, including; Griffith University, Australia (1983, 1996); Université Paris 8 Vincennes-Saint-Denis (1984); University of Calgary, Canada (1988, 1990); University of Canterbury, New Zealand (2003); Australian National University (2004). His house in Bedford, where he lived with his wife Jenny (they married in 1970) was a home from home for scholars from around the world.

Clive helped to create the International Association for the History of Crime and Criminal Justice in 1995 and co-founded this journal in 1997. His intellectual and personal generosity to colleagues cannot be overstated. His characteristic intellectual style was curiosity and encouragement: he trained a generation of researchers to work collaboratively, all feeding in to a criminal justice history milieu which maintained and extended his view of the enterprise as comparative, international, worthwhile, and above all, exciting. Mischievously bringing English sparkling wine to his final Editorial Board meeting in Paris, Clive will be remembered as much for the pleasure of his company - always cheerful, always both interested and interesting - as for the huge legacy of scholarship and research he gifted the world. A self-effacing, inclusive, energetic and patient colleague, it was our great pleasure to work with Clive closely over the years. An energetic scholar to the end, his final work was published posthumously - A Short History of Police and Policing (2021) He will be sorely missed but his work will live on in the field he helped to define and establish.

\section{AUTHOR}

\section{PAUL LAWRENCE}

paul.lawrence[at]open.ac.uk 